\title{
Sciendo
}

\section{Freedom of Expression in Ukraine: (Non)sustainable Constitutional Tradition}

\author{
Tatiana Slinko \\ Olena Uvarova \\ Theory of Law and Legal Philosophy Department, \\ Yaroslav Mudryi National Law University \\ Pushkinska 77, \\ Kharkiv 61024, Ukraine \\ E-mail: t.m.slinko@gmail.com \\ E-mail: uvarova.info@gmail.com
}

Abstract: Freedom of expression is one of the prerequisites for the formation and existence of a democratic society; it belongs among the universal values of paramount importance, because it allows not only to freely express own views, but also reveal the potential of the individual. In addition, it is considered (and it is justified) as one of the main and unconditional achievements of the political reform that is being carried out in Ukraine. The guarantee of freedom of expression, which has the highest political normative content, is, on the one hand, the most important asset of an organic constitution, and on the other hand, serves as the main function of the constitution as a legal source that reflects and responds to the interests of civil society.

However, the real challenge for the unsustainable constitutional tradition that still retains some signs of the post-Soviet model of regulation is the need to balance freedom of expression under the conditions of threats to national security. What should be the proper mechanism for guaranteeing freedom of expression at the constitutional level? How strong is the danger that the state violates the requirement of constitutionality in the case of restrictions on freedom of expression for the sake of national security? How does the post-Soviet tradition of legal regulation manifest itself in deciding which model of guaranteeing freedom of expression is chosen by the state? What is the role of the tradition of respect for personal autonomy and the value of tolerance of a society in guaranteeing freedom of expression? The article is devoted to finding answers to these questions. 
Keywords: constitution, constitutionalism, democracy, guarantee of freedom of expression, liberty, post-Soviet legal tradition, personal autonomy, restriction of freedom of expression

\section{Introduction}

The article discusses one of the very important topics of the Ukrainian constitutional law and politics: the constitutional meaning and limitation of the freedom of expression. Today, one should not need to convince anyone that freedom of expression is one of the foundations of a democratic society. It is a universal and undeniable value. Thanks to the constitutional recognition of the freedom of expression individuals have the opportunity to express their views freely and reveal their potential. It is noteworthy that real freedom of expression is recognized as one of the key achievements of political reform in Ukraine (Slin'ko, 2014, p. 11).

The current understanding of the freedom of expression is based on the fact that it is recognized as the foundation of democracy and at the same time as a prerequisite to other rights and freedoms, such as the right to freedom of peaceful assembly, freedom of conscience and religion, the right to freedom of association, freedom of creativity, and electoral rights. Among others, the right to freedom of expression is of utmost importance. This general position is indisputable (Frovayn, 1997, p. 21).

In this article, we will try to focus on guaranteeing freedom of expression as an element of contemporary constitutionalism, which has key practical significance for Ukraine in a situation where the legal system, which still preserves some manifestations of the post-Soviet legal tradition, faces challenges posed by threats to national security. While developed democracies with sustainable traditions of human rights protection, respect for freedoms, a deep understanding of the principles of interaction between the state and civil society and the need for a reasonable balance between the respective social values are ready for such challenges, the new democracies, who are in the difficult period of transition to the new legal regulation model, based on the human rights approach, demonstrate their weakness both at the doctrinal level and at the practical level.

As far as new democracies are concerned, in addition to the disclosure of general issues, special attention should be paid to the following ones:

1. The role of freedom of expression in promoting democracy, the rule of law, and sustainable development in society; 
2. Risks and dangers related to such problems of new democracies as lack of stable democratic traditions, high level of corruption, and distrust of the population to legal mechanisms for solving problems;

3. The low tolerance of society as a particular problem for post-Soviet countries;

4. The role of balancing of freedom of expression and other core values such as national security in a conflict and post-conflict period, which is a topical issue for Ukraine.

\section{Basic concepts}

The basic concept which constitutes the theoretical foundation of this article is the concept of 'organic constitutionalism'. The idea of organic constitutionalism implies that people are aware of the fact that political power must act in accordance with certain principles, and that political leaders should be elected to their posts to do what is considered right according to these principles and not to assert what they believe are correct. This is the content and functional purpose of organic constitutionalism in general. The main purpose of an organic constitution is not what, but how. Its overriding task is not a material one, but a procedural.

In organic constitutionalism, freedom precedes democracy, it is not its product. True democracy can only exist in a community of politically equal and free actors. Democracy, on the other hand, has the ability to restrict and even completely destroy freedom. Therefore, in organic constitutionalism, freedom, not democracy, is a priority object of protection.

There is one more theoretical concept which is being actively used in the article. This is the concept of modern constitutionalism. The core element of this concept is the idea of limited government.

On the basis of these concepts we will try to justify the main argument of the article which is the following. Constitutionalism is a process. This process, in democratic societies, is founded on liberty as a value and formalized through constitution. Liberty and the limits to the liberty can be understood differently. In modern political systems, the understanding of liberty is formalized and protected through constitutions. In other words, the function of a constitution ought to be to protect liberty as central to constitutionalism, which is rooted in the democratic tradition. 
The central question of the article is: Is it the case in Ukraine? The freedom of expression is a test case.

So, the article first discusses in detail the connection between libertyconstitution-constitutionalism-democracy. And second, this understanding is applied to the protection of freedom of expression in Ukraine.

\section{Liberty as a key essence of organic constitutionalism}

The formation of constitutionalism is seen as an important milestone in the world's democratic state-legal development. Constitutionally designed structure of society and state is inextricably linked to categories such as democracy, freedom and human rights, rule of law, legal/constitutional state (der Rechtsstaat), 'welfare state', social state, etc. (Vytruk, 2012, p. 29). Such a statement is fully consistent with the modern interpretation of the notion of 'constitutionalism' as a system of knowledge of the fundamental values of the democratic system of society and the rule of law. Based on this, we can point out that the basic element of this concept is the doctrine of the essence of the constitution and its functional purpose in the process of regulating social and state relations.

As scholars reveal the essence of organic constitutionalism through the categories of liberty, market and democracy, it seems appropriate to add in this context that liberty is a higher ideal of organic constitutionalism. It is based on democracy but is not its product. Dorsen's (1994) arguments confirm this thesis. He talks about the importance of freedom of expression for the stability of democracy and the rights of the minority in terms of majority's governing: "universal primacy of freedom of expression is based on some very important values", and freedom of expression is important for the self-government in the functioning of democracy, its usefulness is to clarify the truth and use it when it detects violations of law by the authorities, and thus prohibits them to allow personal expressions of people who perceive ideas, especially unpopular, without feeling fear of reprisals. (Dorsen, 1994, p. 275)

Classical sources extend the above statement - democracy exists where all citizens have rights which ensure the original nature of state power from the people and its dependence on the will of the people and formally equal rights to participate in the exercise of public authority (the right to elect and be elected, the right to access to the public service, etc.), as well as personal freedoms, such as freedom of speech, freedom of the press, freedom of peaceful assembly, freedom of association, etc. (Varlamova, 2012, p. 17). Mill wrote: 
No society in which these liberties are not, on the whole, respected, is free, whatever may be its form of government; and none is completely free in which they do not exist absolute and unqualified. The only freedom which deserves the name is that of pursuing our own good in our own way, so long as we do not attempt to deprive others of theirs, or impede their efforts to obtain it. (Mill, 2001[1859], p. 16)

\section{Guaranteeing freedom as the main purpose of the constitution}

Any organic constitution is a guarantor of individual freedom and civil society. A similar vision of the basic law is typical of a modern understanding of constitutionalism, which in the West is equated with the rule of law. Freedom in the political sense has the highest natural normativity — because of this, guarantee of freedom is the main function of the constitution as a legal source that reflects the interests of civil society. According to Rechitsky (1998), organic constitution and freedom are inextricably linked from the very beginning. Ensuring freedom, the constitution provides an autonomous status - autonomous from the state - for the individual and society as a whole (Rechitskiy, 1998, p. 57). According to Hayek (1979), there is only one alternative to constitution - either a free parliament or a free people. That is why it protects the freedom of the individual and civil society as a whole, including from the arbitrariness of the majority in parliament (Hayek, 1979, p. 111).

The clear wording of the essence of the fundamental principles of freedom of expression and beliefs by the leading English advocate of free speech Erskin deserves attention. The basic legal guarantee, in his opinion, is that each person is free to publish "all that his mind or conscience, as if they were not mistaken, are perceived as truth" (Levy, 1963, p. 256).

In the context of the above, it should be added that modern constitutions contain rather different legal guarantees of freedom, but the main thing is considered to be proclaiming freedom as the goal of the state or higher social value; consolidation of freedom as a legal category; establishment of lists of subjective rights and freedoms; abolition of "paternalistic" socio-economic rights; establishment of freedom as a principle of constitutional order; foreseeing procedural safeguards and safeguarding freedom (Rechitskiy, 2012, p. 349). It is believed that the guarantee of freedom in the best constitutional acts corresponds to the idea of Rawls that civil society is not a political association, which is why, according to their prescriptions, society is an open political institution, which creates the maximum opportunities 
for the realization of individual life projects and strategies (Rawls, 1993, p. 11). Consequently, the consolidation of the basic law of freedom as a goal of the state and society corresponds to the classical requirement that values that are equally valid for all citizens, regardless of their place and role in the society, should become the object of constitutional protection.

\section{Freedom of expression as a manifestation of the idea of autonomy: the need to revise the post-Soviet tradition of legal regulation}

There are three convincing reasons for the freedom of expression which ultimately should be considered in conjunction with each other-philosophical, political, and individual.

The most cited and well-known philosophical argument in favour of free expression appears in the mid-nineteenth century writings of John Stuart Mill: the absence of restraints on speech will facilitate discovery of the truth (Mill, 2001[1859], p. 12). In more contemporary parlance, the truth theory was restated by US Supreme Court Justice Oliver Wendell Holmes in terms of the marketplace of ideas (Abrams v. US [1919], 250 US 616, 630-631 (dissenting opinion)).

The political reason is about free expression as essential to a well-functioning democratic self-government. Under the democracy or self-government theory, freedom of speech (and expression) is a critical right specified in the First Amendment because it is essential for "collective self-determination" by the citizens (Fiss, 1992, p. 256).

The individual reason for free expression is based on the dignity of the individual and the right of self-fulfilment. This reason includes numerous theories, all of which relate to the individual rather than society at large. The individual reason is a major departure because it posits that free expression is a desirable end unto itself because it is an essential aspect of human autonomy and dignity (Melkonian, 2012, p. 12).

We emphasize the importance of all three arguments. But we should note that the feature of the post-Soviet tradition of law is the neglect of the importance of personal autonomy, disregard for it.

The value of autonomy is explained by its origin from the idea of the dignity of a human being (Sellers, 2008, p. 9). Its nature is often disclosed in reference to 
the speech of Pico della Mirandola, Italian Renaissance, On the Dignity of Man (1496): "The dignity of man lies in the fact to act as the creator of own essence. Man can be what he wants to be." (Pico Della Mirandola, 1996[1496], p. 10) This aspect of human dignity has been embodied in the idea of personal autonomy (Alldridge \& Brants, 2001), which in its simplest definition is understood as self-regulation (self-rule, self-legislation) and self-government, when the emphasis is placed on the possibility of self-direction, free from external forces, or, according to the figurative expression of Rawls (1993), self-authorship.

Correlation with freedom makes the idea of autonomy extremely attractive. It is understood as the right not to interfere with the state ("to keep it at a distance of the elongated hand" (Taylor, 2005, p. 604)). The lack of a sustainable tradition of respect for personal autonomy was the main reason for excessive state interference with freedom of expression in the post-Soviet tradition of legal regulation.

\section{Was constitutional protection of the freedom of expression in the post-Soviet reality organic?}

The system of constitutional guarantees gives some idea about the attitudes to the freedom of expression and speech in a specific society. It is not enough just to declare the right to freedom of expression and speech, it is important to create certain conditions and identify the means by which the existence of freedom of speech and information becomes a reality, and this is possible only in a democratic society. Thus, without the corresponding guarantees proclaimed in the Constitution and laws of Ukraine, rights and freedoms become "an empty sound" (Pashyns'kyy, 2006, p. 62).

To complete the consideration of the issue and understand the state of affairs with the guarantee of freedom of expression, let us dwell on the fact that the provision of guarantees is typical for the old and new constitutions such as constitutions of the USA (1787), Switzerland (1874, 1999), Spain (1978), Japan (1947), Macedonia (1991), Bulgaria (1991), Slovakia (1992), France (1946), and Poland (1997). Moreover, according to the constitutions of post-totalitarian countries, freedom is recognized as a higher social value. In particular, relevant provisions are contained in the basic laws of Croatia (1990), Uzbekistan (1992), Turkmenistan (1992), Kazakhstan (1993), Russia (1993), Kyrgyzstan (1993), Brazil (1998), and others.

However, the guarantee of freedom of expression in the abovementioned constitutional acts remains behind the level of protection of civil liberties, 
for example, in the US. This is easily explained by the fact that in American constitutional doctrine, and country as a whole, freedom of speech is highly valued, and laws that protect freedom of expression, information, and press are adopted on the basis of the First Amendment to the US Constitution. The Congress should not interfere in the implementation of individual rights to free expression and should not adopt any laws that restrict fundamental freedoms.

It is noteworthy that the guarantee of freedom of expression in Ukraine begins with the mention in the Preamble of the Constitution that the Basic Law of Ukraine was adopted for the protection of human rights and freedoms. Unfortunately, despite the recommendation of the International Forum in Guti, Synehore (January 11-13, 1996), the category 'freedom' was not included in the official draft of the Constitution of Ukraine as one of the highest social values (Rechitskiy, 2012, p. 355). Article 3 of the Constitution of Ukraine states that human rights and freedoms, as well as their guarantees, determine the content and direction of the state's activities.

It could be given a logical explanation. As the study of the constitutional aspects of freedom of expression in Soviet Ukraine shows, the real freedom of expression and thought was simply impossible at that time. It is also necessary to add that the Ukrainian constitutionalism of the Soviet era was not an independent legal phenomenon. The road to constitutional recognition of the right to freedom of expression and freedom of speech was long and it began with the rejection of the undemocratic regime. According to the Ukrainian political scientist Kuliyk, "the fundamental feature of the media system of independent Ukraine is post-Sovietism, that is, a radical change in the social role in comparison with the Soviet times and the simultaneous preservation of many Soviet features in the media itself and in their social context" (Kulyk, 2010, p. 177).

Proclaimed by the Constitution of Ukraine (1996, Art. 15), the principle that public life in Ukraine is based on political and ideological diversity, is one of the basic principles of the Ukrainian state. Moreover, the importance and significance of the abovementioned norm is confirmed in the decision of the Constitutional Court of Ukraine (2001; case about youth organizations). It formulates the legal position according to which "the principle of diversity of social life is a starting point in defining the principles of the implementation of this constitutional right and the establishment of civil society institutions, which is composed of various associations of citizens representing certain ideological and other views, the interests of different social groups and individuals" (Constitutional Court of Ukraine, 2001).

In this context it should be noted that the international community now understands that freedom of thought and speech, free expression of views and beliefs are necessary 
for people, and so is the freedom of public discussion of issues that are important. Moreover, it is a form of existence of a democratic tolerant society. Ideological diversity means the free existence of various political and other views, schools, ideas in society, as well as the ability to publicly promote them with the help of mass media and publicly defend them. The principle of ideological pluralism means a ban on the establishment of a mandatory ideology by the state, that it is a taboo to establish in the law the system of compulsory views or norms that citizens will share, study and propagate under the threat of persecution and punishment.

Establishing of political and ideological diversity in the Constitution of Ukraine, in fact, attests that "Ukrainian democracy is a constitutional weapon", which will protect it from attacks that occur in all societies that are trying to say goodbye to the totalitarian past. The norms of Ukrainian Constitution are in line with generally accepted standards: the Universal Declaration of Human Rights, the Convention for the Protection of Human Rights and Fundamental Freedoms, the International Covenant on Civil and Political Rights, and the Final Act of the Security and Cooperation Organization (OSCE) in August 1975 in Helsinki and other OSCE documents.

\section{Table 1. Ratings of freedoms and human rights}

Ukraine's place in the ranking (total number of countries)

Ukraine's index (maximum indicator)

\begin{tabular}{|l|c|c|c|c|c|}
\hline Rating / Year & $\mathbf{2 0 1 4}$ & $\mathbf{2 0 1 5}$ & $\mathbf{2 0 1 6}$ & $\mathbf{2 0 1 7}$ & $\mathbf{2 0 1 8}$ \\
\hline Reporters Without & 127 & 129 & 107 & 102 & 101 \\
Borders: Press Freedom & (total 180) & $(180)$ & $(180)$ & $(180)$ & $(180)$ \\
Index & 36.93 & 39.10 & 32.93 & 33.19 & 31.16 \\
0 - highest, 100 - lowest) & (total 100) & $(100)$ & $(100)$ & $(100)$ & $(100)$ \\
\hline The Democracy Index & $92(167)$ & $88(167)$ & $86(167)$ & $83(167)$ & $84(167)$ \\
& $5.42(10)$ & $5.70(10)$ & $5.70(10)$ & $5.69(10)$ & $5.69(10)$ \\
\hline Freedom House: & - & - & $61(100)$, & $61(100)$, & $62(100)$, \\
Freedom in the World & Partly free & Partly free & Partly free & Partly free & Partly free \\
\hline The World Justice Project & $84(99)$ & $70(102)$ & $78(113)$ & \multicolumn{2}{|c|}{$77(113)$} \\
Rule of Law Index & & & & \multicolumn{3}{|l}{} \\
\hline
\end{tabular}

Sources: EIU Democracy Index, 2018; Freedom House, 2019; IMI, n.d.; Reporter ohne Grenzen, 2017; Reporters without Borders, 2019; WJP, 2018

The situation with freedom of expression in Ukraine, compared to previous years, has improved. The Freedom of the Press Ranking of the international organization Freedom House (which analyses the degree of freedom of speech and media in the world), published annually on its website, noted that Ukraine is progressing and, 
ranked 113th, it has received the status of "partially free" (with rating 53) (Freedom House, 2017b). However, the rating 'Freedom on the Net' noted that in Ukraine there is a deterioration of internet freedom in view of the introduction of unprecedented censorship of Russian internet resources (Freedom House, 2017a).

\section{The constitutionality of restrictions on freedom of expression in the period of conflict and in terms of threats to national security}

It is known that freedom entails risks. Therefore, freedom itself calls us to tolerate things to which we may feel disgust or even hatred, which could undermine our faith in God, country or all of humanity. Globalization, which provides quick access to any information, regardless of borders and cultures, leads to the fact that people who hold different views of the world, with different beliefs and different faith, live much closer to each other, which makes the need for tolerance even more acute.

It is believed that the idea of tolerance appeared in the 17th century as a response to religious conflicts. However, while at that time there were conflicts based on theological disagreements, now there are conflicts caused by political contradictions (Kymlicka \& Cohen-Almagor, 2000, p. 89). For a long time, pluralism was not characteristic of the requirements for the restriction of rights and freedoms: such restrictions should not threaten the right itself; the state must prove their necessity in a democratic society; they must be provided for by law and pursue a legitimate aim; restrictions should be proportional (Vovk, 2015, p. 67).

Defining the limits of "freedom" is not so simple (Melkonian, 2012, p. 4). Interestingly, even the First Amendment's protection of speech from federal regulation was understood to have limits. The US Constitution included no language about the "abuse of liberty", but Joseph Story was dismissive of claims of unlimited liberty in his influential 1833 Commentaries on the Constitution of the United States, "that this amendment was intended to secure to every citizen an absolute right to speak, or write, or print, what ever he might please, without any responsibility, public or private therefor, is a supposition too wild to be indulged by any rational man." (Story, 1833) In 1877, the Supreme Court held that the federal government had the right to prohibit a host of "immoral" material from the mail, such as "lewd" books and information about contraceptives. And during World War I, amid the heated debates of patriots and pacifists, this repressive impulse reached a crescendo with the passage of the Espionage Act of 1917 and the Sedition Act of 1918. Combined, the two acts made it illegal to interfere with 
the war effort or the draft or criticize the government, the army, the Constitution, or the war. There were approximately 2,000 prosecutions for speech crimes during the war, which led to roughly 1,000 convictions. Individuals went to jail for expressing even mild opposition to the war-their convictions capped the nineteenth century's long neglect of meaningful protections for individual rights of expression.

After the war, the Supreme Court heard appeals on some of these convictions and began to seriously ponder the meaning of the First Amendment for the first time. At first, the court was dismissive of claims to free speech. In the three First Amendment cases decided in the spring of 1919, the court unanimously upheld the convictions of all three speakers. Charles Schenck went to jail for distributing leaflets that encouraged drafted men to protest or register as conscientious objectors. The court found that such speech created a "clear and present" danger of disrupting the draft and that regulating such speech was not a violation of the First Amendment but appropriate state action (the speech was deemed the moral equivalent of falsely shouting "Fire!" in a theater). The Socialist Party leader and perennial presidential candidate Eugene Debs went to jail for a speech that promoted socialism and criticized the war. And Jacob Frohwerk, editor of a small German-language newspaper in Kansas City, went to jail for publishing a sequence of critical articles about Britain and the war effort. The last decision suggested how much censorship the clear and present danger test allowed. The court conceded that Frohwerk had not made "any special effort to reach men who were subject to the draft," but argued that it was "impossible to say that it might not have been found that the circulation of the papers was in quarters where a little breath would be enough to kindle a flame." (Lebovic, 2016, p. 11)

Today the digital age offers its users an abundance of possibilities to provide people with information and search for original sources. Freedom of expression may change its form, but arguments for freedom of speech remain the same, even in the new age (Hallberg, 2017, p. 16).

In Part 3 of Article 34 of the Constitution of Ukraine there is a limit of the exercise of the expression freedom and other corresponding rights, insofar as it concerns the interests of national security, territorial integrity or public order, in order to prevent disturbances or crimes, protect public health, protect the reputation or rights of others, prevent the disclosure of information received confidential, or support for the credibility and impartiality of justice. According to Part 2 of Article 64 of the Constitution, these restrictions may be supplemented by those which are established in conditions of martial law or state of emergency. 
The Constitution of Ukraine (Government of Ukraine, 1996), which has been written in Eastern European samples, contains 13, and, taking into account the martial law and the state of emergency, 15 restrictions of fundamental freedoms of expression and speech. In our opinion, the issue of restricting freedom of expression and freedom of information in Ukraine should be resolved in accordance with the European doctrine of freedom of speech.

Often in the laws of post-totalitarian countries, such concepts as 'interests of society', 'protection of the rights and freedoms of other people', 'social orientation of the economy', 'harm to society', 'motives of social necessity', 'interests of national security', 'information sovereignty', 'information security', 'objective truth' and others are used in order to directly or indirectly suppress the heuristic abilities of the individuals (Rechyts'kyy, 2007, p. 30).

The Ukrainian state ignores the constitutional prohibition of censorship (Part 3 of Art. 15). This is clearly evidenced by the list of newspaper headlines only in the last few years, among them 'The Rada allowed to fine the channels and radio for separatism' (11 Jan 2016); 'The film about the Volyn tragedy was canceled in Kyiv' (17 Oct 2016); 'Poroshenko put into operation the decision of the National Security and Defense Council, which provides blocking sites' (18 Feb 2017); 'Ukraine has fallen again in the ranking of freedom of the Internet' (14 Nov 2016); 'SBU is preparing to block another 100 sites with Russian propaganda' (12 Feb 2019); 'Freedom of speech or security: how did Europe break in on the prohibition of social networks and Yandex' (17 May 2017), and many others.

In this aspect the case on the constitutionality of Ukraine of certain provisions of the Law of Ukraine 'On cinematography' and Article 6 of the Law of Ukraine 'On television and radio' is a subject of special interest. Currently, consideration of this case in the Constitutional Court of Ukraine is taking place. The provisions of the Law of Ukraine 'On cinematography' establish a significant restriction of the right to free dissemination of information as they:

- hinder the dissemination of information based on the inclusion of a film's participant to the List of Persons who Seriously Endanger National Security; and

- relate to the rights and interests of a wide range of persons - those who are participants of the film, those who are involved in its creation and distribution, as well as those who wish to watch the relevant film.

The restriction on the distribution of information does not depend on its content, only the fact that the person who has been included in the appropriate List and participates in the film is sufficient to restrict, without the need for an analysis of the content of the information. 
The purpose of such legislative regulation is to introduce a legal mechanism for the protection of Ukraine's national security in the information sphere by restricting in Ukraine any form of propaganda used by the aggressor state.

Prohibition of the distribution of films only because a person who is participating in the film has been included in the "ban list", without analysing the content of the disseminated information and without checking it for the presence of threats to national security, violates the Constitution of Ukraine.

It can be argued that in this case the essence of the right to disseminate information is leveled out, since the prohibition on its dissemination is absolute and does not relate to the content of this information itself, such prohibition has the nature of censorship on the basis of involvement in the creation of such information of a particular person (Government of Ukraine, 2018).

\section{Conclusions}

Ukraine is at the initial stage of assimilating the paradigm of organic constitutionalism, one of the basic values of which is the right to freedom of expression that can be realized only in a democratic regime, interested in the manifestation of the diversity of opinions. Unreasonable restrictions on freedom are unacceptable for such a regime.

If Ukraine aspires to organic constitutionalism, it is necessary to strengthen the guarantees of freedom of expression by bringing them to European and world standards. We are talking about the introduction of a three-component test, according to which the restriction of freedom of expression can occur only on the basis of law and in cases where it is consistent with the legitimate aim and is necessary in a democratic society.

It is also worth emphasizing that, after introducing amendments to the current Constitution in February 2019 regarding the official political course of Ukraine, the orientation of all branches of state power of Ukraine on the values of EuroAtlantic constitutionalism (in particular, the First Amendment in the context of the Bill of Rights of 1791, Art. 13 of the Charter of Fundamental Rights of the European Union in 2009, etc.) is normatively binding (Rechyts'kyy, 2019).

Transitional societies like Ukraine often form their legal systems through direct and indirect borrowing, copying Western normative models and samples. As a result, in a domestic context, one can often observe a phenomenon in which the formal ("rhetorical") constitutionalism is significantly outpacing informal legal 
achievements. At the same time, the consolidation of a number of constitutional values and guarantees may enter into a sharp contradiction with the real mentality of the political leaders of the country.

Is it permissible to introduce the collective responsibility of authors, performers, and producers of the film by refusing to distribute and display films in the case of an individual, who is a participant of the film, has been included in the "list of persons who threaten national security"? The answer to this question seems to be negative ("inadmissible"). Society never knows for sure why a particular person has been declared to be a threat to national security. If the country has cruel authoritarianism and dictatorship, most of its creative elite risk to be in the status of "persons threatening national security". If the country is the embodiment of a Western-style liberal democracy, the announcement of anyone by its ideological enemy or political opponent does not mean extending such an assessment to a prohibition of the demonstration or sale of its creative achievements on the market. Actually, the principle of tolerance works in the Western world exactly in such a way.

Unlike totalitarian and authoritarian regimes, countries of Western-style liberal democracy remain tolerant even in a situation of deep ideological confrontation. Of course, this is the case in ideological conflicts, and not a violation of a criminal or other branch of law that has been proven in court. The provided analysis suggests that limitations to the freedom of expression in Ukraine do not correspond to the understanding of constitutionalism based on liberty as a value. The restrictions go beyond what is necessary. The current situation is explained by a complex post-Soviet transformation, a weak democratic, constitutional tradition and the current political situation.

Tetiana Slinko, PhD in law, is an associate professor at the Chair of the Department of Constitutional Law of Ukraine, Yaroslav Mudryi National Law University. Her research activity has resulted in almost 150 scientific, educational and methodical works, of which the monographs (in co-authorship) are Legal Bases of Formation and Functioning of Public Authorities in the Context of European Integration (2010), and Democratic Principles of Organization and Functioning of High Bodies of State Power of Ukraine (2013). She is trained under the Tempus-Tacis Program (TEMRUS) of the European Commission at the Universidad de Oviedo (Spain, Autonomous Region of Asturias). She has repeatedly provided scientific opinions on requests from the legislature and the judiciary, exploring the problems of media law in the context of Ukraine's approximation to European information standards. Since October 2016, she has been managing the certification program Electoral Law and Electoral Technologies. 
Olena Uvarova, PhD in law, is a lecturer in the Theory of Law Department, head of the International Lab on Business and Human Rights at the Yaroslav Mudryi National Law University. Dr. Uvarova is the author of more than 80 scientific papers on the theory of law, human rights, gender equality, anti-discrimination policy, business and human rights. Since 2014, she has been a member of the editorial board of the journal Philosophy of Law and General Theory of Law (EBSCO Publishing). Some of her completed projects include 'Promoting Human Rights and Gender Equality in Ukraine through the Implementation of International Legal Instruments', 'Monitoring of Court Decisions Regarding Gender Discrimination, Focusing on the Application of Ukrainian Legislation and International Law', 'Tolerance in Post-conflict Societies', etc.

\section{Bibliography}

Alldridge, P \& Brants, Ch., eds. (2001), Personal Autonomy, the Private Sphere and the Criminal Law: A Comparative Study, Oxford \& Portland: Hart Publishing.

Barabash, Y. (2013), Demokratiya yak konstytutsiyna ideolohiya: ukrayins'kyy variant. Demokratychni zasady orhanizatsiyi $i$ funktsionuvannya vyshchykh orhaniv derzhavnoyi vlady Ukrayiny [Democracy as a constitutional ideology: Ukrainian variant. Democratic principles of organization and functioning of the highest bodies of state power in Ukraine], Kharkiv: Pravo.

Constitutional Court of Ukraine (2001), Rishennya Konstytutsiynoho Sudu Ukrayiny [Decision of the Constitutional Court of Ukraine, case about youth organizations], no. 18-pп/2001, 13.12.2001. Retrieved from http://zakon0.rada.gov.ua/laws/show/ v018p710-01 [accessed 10 Apr 2019]

Constitution of Ukraine (1996), Konstytutsiya Ukrayiny, Zakon Ukrayiny [The Law of Ukraine], no. 254k/96-VR, 28.06.1996, Vidomosti Verkhovnoyi Rady Ukrayiny, no. 30 , p. 141.

Dorsen, N. (1994) Priroda i predely grazhdanskikh svobod v USA. Prava cheloveka nakanune XXI veka [The nature and limits of civil liberties in the United States. Human rights on the eve of the 21st century], Moskva: Progress.

EIU Democracy Index (2018), The Economist Intelligence Unit. Retrieved from http:// www.eiu.com/topic/democracy-index [accessed 15 Apr 2019]

Fiss, O. (1992), 'The irony of free speech,' University of Chicago Law Review, vol. 59, pp. 255-301. https://doi.org/10.2307/1599938

Freedom House (2017a), Freedom of the Net. Retrieved from https://freedomhouse.org/ sites/default/files/FOTN\%202017_Ukraine.pdf. [accessed 15 Apr 2019]

Freedom House (2017b), Freedom of the Press. Retrieved from https://freedomhouse. org/report/freedom-net/2017/ukraine_[accessed 10 Feb 2019] 
Freedom House (2019), Freedom in World: Ukraine. Retrieved from https:// freedomhouse.org/report/freedom-world/2019/ukraine-translation [accessed 10 Feb 2019]

Frovayn, Y. (1997), Svoboda vyrazheniya svoyego mneniya v Konventsii o zashchite prav cheloveka [Freedom of expression in the Convention for the Protection of Human Rights], Strasbourg: Monitor/Inf.

Government of Ukraine (2018), Konstytutsiyne podannya shchodo vidpovidnosti Konstytutsiyi Ukrayiny (konstytutsiynosti) okremykh polozhen' Zakonu Ukrayiny "Pro kinematohrafiyu” ta polozhen' statti 6 Zakonu Ukrayiny "Pro telebachennya $i$ radiomovlennya" [Constitutional petition on the compliance of the certain provisions of the Law of Ukraine 'On cinematography' and the provisions of Article 6 of the Law of Ukraine 'On television and radio broadcasting' with Constitution of Ukraine (constitutionality)], no. 325/0/01-1, 09.07.2018. Retrieved from http:// www.ccu.gov.ua/sites/default/files/3_3492.pdf. [accessed 10 Apr 2019]

Hallberg, P. \& Virkkunen, J. (2017), Freedom of Speech and Information in Global Perspective, New York: Palgrave Macmillan. https://doi.org/10.1057/978-1-349-94990-8

Hayek, F. (1979), Law, Legislation and Liberti, vol. 3, Chicago: University of Chicago Press.

IMI (n.d.), Barometr svobody slova [Barometer of freedom of speech], Institut Massovoi Informatsii. Retrieved from http://imi.org.ua/monitoring-types/barometr-svobodyslova/ [accessed 10 Apr 2019]

Kolodiy, A. \& Oliynyk, A. (2004), Prava lyudyny i hromadyanyna v Ukrayini [Human rights and rights of citizens in Ukraine], Kyiv: Yurinkom Inter.

Kulyk, V. (2010), Dyskurs ukrayins'kykh mediy: identychnosti, ideolohiyi, vladni stosunky [Discourse of the Ukrainian media: identity, ideology, power relations], Kyiv: Krytyka.

Kymlicka, W. \& Cohen-Almagor, R. (2000), 'Democracy and multiculturalism,' in R. Cohen-Almagor (ed.) Challenges to Democracy: Essays in Honour and Memory of Isaiah Berlin, London: Ashgate Publishing Ltd.

Lebovic, S. (2016), Free Speech and Unfree News: The Paradox of Press Freedom in America, Cambridge, MA: Harvard University Press. https://doi.org/10.4159/9780674969612

Levy, L. (1963), Freedom of Speech and Press in Early American History: Legacy or Suppression, New York: Harper \& Row.

Melkonian, H. (2012), Freedom of Speech and Society A Social Approach to Freedom of Expression, Cambria Press.

Mill, J. S. (2001[1859]), On Liberty, Kitchener: Batoche Books. Retrieved from https:// socialsciences.mcmaster.ca/econ/ugcm/3113/mill/liberty.pdf [accessed $10 \mathrm{Apr}$ 2019] 
Pashyns'kyy, V. (2006), 'Pravovi harantiyi konstytutsiynykh prav i svobod viys'kovosluzhbovtsiv' [Legal guarantees of constitutional rights and freedoms of servicemen], Pravo Ukrayiny, no. 5, pp. 61-65.

Pico Della Mirandola, J. (1996[1486]), On the Dignity of Man, transl. by A. R. Gaponigri, Chicago: Gateway Editions.

Rawls, J. (1993), Political Liberalism, New York: Columbia University Press.

Rechitskiy, V. (1998), Konstitutsionalizm. Ukrainskiy opyt [Constitutionalism. Ukrainian experience], Kharkov: Folio.

Rechitskiy, V. (2012), Politicheskiy predmet konstitutsii [Political subject of the constitution], Kyiv: Dukh i litera.

Rechyts'kyy, V. (2007), Symvolichna real'nist' i pravo [Symbolic reality and law], L'viv: VNTL-Klasyka.

Rechyts'kyy, V. (2019), Pro tsenzuru (z pryvodu perevirky na vidpovidnist' Konstytutsiyi Ukrayiny okremykh polozhen' zakoniv Ukrayiny "Pro kinematohrafiyu” ta "Pro telebachennya i radiomovlennya") [On censorship (regarding the verification of certain provisions of the Laws of Ukraine 'On cinematography' and 'On television and radio broadcasting' in accordance with the Constitution of Ukraine)]. Retrieved from http://khpg.org/index.php?id=1550672973 [accessed 10 Apr 2019]

Reporter ohne Grenzen (2017), Rangliste der Pressefreiheit 2017. Retrieved from https:/www.reporter-ohne-grenzen.de/fileadmin/Redaktion/Presse/Downloads/ Vorab/Liste.pdf [accessed 10 Apr 2019]

Reporters without Borders (2019), 2019 Press Freedom Barometer. Retrieved from https://rsf.org/en/ranking [accessed 10 Apr 2019]

Sellers, M. (2008), 'An introduction to the value of autonomy in law,' in Autonomy in the Law, Cham: Springer, pp. 1-10. https://doi.org/10.1007/978-1-4020-6490-6

Skrypnyuk, O. (2011), 'Svoboda dumky i slova: konstytutsiyno-pravovi harantiyi v Ukrayini' [Freedom of thought and speech: constitutional and legal guarantees in Ukraine], Yurydychna Ukrayina, no. 3, pp. 28-32.

Slin'ko, T. (2014), 'Konstytutsiyno-pravovi harantiyi svobody slova' [Constitutional and legal guarantees of freedom of speech], Nashe parvo, no. 9, pp. 9-12.

Slin'ko, T. \& Kushnirenko, A., eds. (2012), Svoboda slova v usloviyakh narodovlastiya. Konstitutsionno-pravovyye osnovy narodovlastiya $v$ Rossii $i$ v Ukraine [Freedom of speech in terms of democracy. Constitutional and legal foundations of democracy in Russia and Ukraine], Kharkov: Pravo.

Taylor, R. S. (2005), 'Kantian personal autonomy,' Political Theory, vol. 33, no. 5, pp. 602-628. https://doi.org/10.1177/0090591705278397

Varlamova, N. (2012), Konstitutsionalizm: variativnost'ponyatiya [Constitutionalism: the variability of the concept], Moskva: Institut prava i publichnoy politiki.

Vitruk, N. (2012), Konstitutsionalizm: real'nyy ili imitatsionnyy? [Constitutionalism: real or imitation?], Moskva: Institut prava i publichnoy politiki. 
Vovk, D. \& Uvarova, O. (2015), Svoboda relihiyi i svoboda slova pislya Charlie Hebdo [Freedom of religion and freedom of speech after Charlie Hebdo], Kharkiv, pp. 66-84.

WJP (2018), World Justice Project Rule of Law Index, 2017-2018. Retrieved from https://worldjusticeproject.org/our-work/wjp-rule-law-index [accessed $10 \mathrm{Apr}$ 2019] 